\title{
Ou o poema contínuo, de Herberto Helder
}

\author{
Mauricio Salles Vasconcelos \\ Universidade de São Paulo
}

á há algum tempo tornada objeto de culto entre poetas, estudiosos e diferentes leitores brasileiros, a produção do português Herberto Helder somente agora se encontra editada em nosso país, tendo como base a reunião de seus livros publicada, originalmente, em 2004, pela Assírio \& Alvim (Lisboa) com o título Ou o poema contínuo. Não é de hoje, também, que essa criação excessiva, multiforme e, ao mesmo tempo, severa, dotada de precisão, fundada em sua própria essencialidade, vem repercutindo como um dos conjuntos poéticos mais importantes realizados em língua portuguesa.

Por força de um dizer impactante, capaz de inaugurar andamentos rítmico-conceituais e percepções imagéticas no compasso de uma indagação constante e consistente acerca da linguagem, do lugar da poesia e do poeta, o trabalho de Helder constitui-se em uma das poucas grandes referências (um pólo de radiação e radicalidade estéticas cada vez mais visível) das poéticas contemporâneas escritas em português. A presente edição de Ou o poema contínu só faz intensificar - de um a outro livro ali enfeixado - a sutil e, ao mesmo tempo, influente realidade de uma dicção.

Desde $A$ colher na boca (1961), livro inicial, a descida às nascentes da poesia (ou o ingresso em seu continuum) não rende da parte de Helder nenhuma espécie de sagração essencialista da palavra nem tampouco o exercício atomizador do texto por obra de uma inscrição nas vanguardas da época. Tudo excede e se depura. Pela via de uma autonarratividade que dialoga com a prosa e a teoria sem se parasitar em nenhuma proposição prévia, em nenhum programa, a escrita de $\mathrm{Ou}$ o poema contínuo logo se instaura em um campo de experimentação, do qual não se retira (ao longo de mais de quarenta anos de produção) o ali- 
nhamento poemático do verso, por mais tortuoso que se faça, assim como um princípio de inacabamento a norteá-lo.

Herberto Helder vai ao cerne da linguagem e do mundo (item e incurso fundamentais para o poeta), sem refutar o pacto polivalente da nomeação, que circula do corpo ao cosmos, no engendramento de uma maquinismo verbal autônomo e, a um só tempo, autocentrada. Para isso convergiram, na escrita do autor, várias vertentes da poesia, das mais modernas às mais remotas (das fontes obscuras do romantismo ao ideário surrealista, passando pela poesia de Safo à oralidade de vários poemas de povos não-ocidentais traduzidos por ele nos volumes intitulados As magias). A leitura da última súmula do que se pode reconhecer como obra completa de Herberto Helder propicia esse sentido de remapeamento de linhas de escrita provenientes de inumeráveis épocas e tendências, conduzidas, à medida que as palavras reverberam em diferentes direções, no sentido de outra montagem e duraşão, de forma a amplificar uma certa noção de livro e de poesia, fundamentada tãosomente na literatura.

Por mais que se identifique a combustão bem engrenada de poemactos extraídos de Artaud, Bataille, Michaux (de todo modo, uma genealogia bem peculiar de autores contemporâneos do surrealismo), os campos magnéticos do texto helderiano compõem muito mais uma sonda do que a imantação de possíveis estilos. O que soa em seus escritos é o encaminhamento de um vasto referencial da história da poesia - assim como de suas encruzilhadas conceituais - rumo a uma teatralização de seu campo de força ou a uma exposição/projeção visualmente dinâmica e mobilizante, no estrito espaço do poema, concebido como longa, fragmentária formulação.

Tudo se dispersa e faz núcleo na poética de Herberto Helder. Quando publica, em 1977, a prosa teórico-performativa de Photomaton \& Vox, estava ele a definir os componentes básicos da radicação de sua poesia nos espaços de partilha e contágio entre os signos da contemporaneidade. Ali, o autor teorizava, no mesmo instante em que dispunha na alínea do experimento de linguagem - na faixa de construção do poema contínu - o ponto de alteridade em que se move sua palavra situada entre som e imagem de um mundo concebido, revertido como técnica (imagem de mundo).

Há um sentido, pois, de atualidade, quando se trava contato com o mesmo novo livro de Helder, justamente por seu vínculo com a variação (do conjun- 
to, da idéia de obra), em sincronia com a mais recente concepção de uma possível "linguagem poética" ou, com a elaboração de um projeto que se entremostra, de um livro a outro. "[...] cerraria a boca, como se a sepultara num silêncio plantado/ de muitas presenças fortes/ como sal” (HELDER, 2006: 33).

Photomaton \& Vox. Um espaço verbal é composto sob o alinhamento de versos numa longa pauta de palavras em ritmo, de modo a melhor se projetar como movimento, por meio de uma escrita possível de ser definida como cinemática. "e levanto a mão e explode cinematograficamente a imagem" (HELDER, 2006: 338). Espaço reconhecível por força de sua dicção, de toda uma imagética (um traço que define Herberto Helder pelo que tem de pregnante a visualidade de seus textos, para todos que já o leram), em que se sinalizam os enlaces e as fronteiras da poesia. Um Plano-Poema se ergue e instala as pulsações mais próprias, mais abismadas, da palavra, além de suas extensões, seu exterior-noite-mundo (da forma como bem estudou o crítico João Amadeu da Silva).

O que sempre impressiona na leitura dessa poética é a potência simultânea de autoposição e descentramento da escrita. Quanto mais se dissemina e indetermina a corrente de seu fluxo enunciativo, o poema contínuo de Helder abre órbitas surpreendentes de gravitação de imagem-conceito-som no circuito cerrado de um volume de versos.

Seus textos se lançam para um campo de percussões conceituais em que a imaginação desbrava uma esfera de intercessões e acessos a planos inexplorados. O autor de Última ciência (um de seus últimos volumes publicados) re-situa a constelação moderna de signos da poesia em uma rotação concentrada nos pólos do mundo e da terra, da corporalidade e das instâncias imateriais do universo. "... - como se fosse/ respiração e sangue e potência/ planetária: criaturas, objetos,/ as ordens nominais que os arrancam dos limbos." (HELDER, 2006: 406).

O contato com a presente edição de sua poesia completa confirma algo possível de se conceber como a crescente contemporaneidade de um autor cada vez mais próximo da sensibilidade de leitores situados no impasse entre mundo globalizado e pensamento planetário (nos termos em que o concebe o filósofo grego Kostas Axelos), entre a planificação das diferentes sociedades e a abertura para sondagens, expansões/experiências ambientais. Ou o poema con- 
tínuo - cartografia de um dizer em experimento, à altura da técnica e da idéia de mundo (no contexto mesmo da mundialização), empenhado, contudo, em traçar cosmogonias no interior de uma cultura tecnológica, a cada dia mais consolidada.

Ler Herberto Helder hoje ou conhecer cada um de seus livros reunidos numa edição nacional possibilita a afirmação da força insubstituível, mais do que presente, da poesia - no momento mesmo em que se evidencia a realização, em processo, daquele que não pára de se revelar como um dos principais poetas deste tempo, agora.

\section{Referência Bibliográfica}

HELDER, Herberto. Ou o poema contínu. São Paulo: A Girafa, 2006. 